\title{
Performance of EUS-FNA for mediastinal lymphadenopathy: impact on patient management and costs in low-volume EUS centers
}

\author{
M. M. C. Hirdes · F. P. Vleggaar
}

Published online: 1 April 2011

(C) The Author(s) 2011. This article is published with open access at Springerlink.com

We read with interest the letter of Dr. Batsis regarding our Surgical Endoscopy article in which we assessed the clinical value of endoscopic ultrasound-guided fine-needle aspiration (EUS-FNA) for mediastinal lymph nodes in lowvolume EUS centers [1].

We fully agree with the author that EUS-FNA is an invasive method for staging and sampling mediastinal lymphadenopathy that may be associated with complications such as perforations. In addition, FNA is technically demanding, and it is not easy to determine which lymph node to puncture because current sonographic criteria for malignant lymph nodes lack specificity [2]. However, EUS-FNA does seem to play a major role in determining the surgical approach [3], and more important, seems to avoid futile surgical interventions in both low- and highvolume EUS centers [1, 4].

Indeed, it would be desirable to avoid such an invasive method, for instance, by measuring biomarkers in serum samples. However, we believe that these diagnostic options currently are not clinically available.

An interesting alternative that may avoid FNA, or at least decrease the number of ultrasound-guided punctures, is EUS elastography. This technique, a further development of the well-known breast ultrasound fremitus technique, is based on the fact that a change in tissue resulting in malignant, fibrotic, inflamed or normal tissue may alter elasticity [5].

Instead of asking the patient to hum for vibration during color Doppler examination of the breast, for EUS tissue

M. M. C. Hirdes $(\bowtie)$ - F. P. Vleggaar

Department of Gastroenterology and Hepatology, University

Medical Center Utrecht, PO Box 85500, 3508, GA, Utrecht,

The Netherlands

e-mail: M.M.C.Hirdes@umcutrecht.nl elasticity imaging, vibrations and compressions are provided physiologically by vascular pulsation and respiratory motion. The calculation of tissue elasticity distribution is performed in real time, and the elasticity results are presented in different colors projected over the conventional B-mode image, with malignant tissue appearing in blue, fibrosis in green, normal tissue in yellow, and fat in red [6]. Unfortunately, only the Pentax EUS-scope (EG 38-UT; Pentax Europe Gmbh Hamburg, Germany) but not the Olympus EUS scope (GF-UCT140; Olympus, Hamburg, Germany) is equipped with this diagnostic tool.

Initial research focusing on breast cancer showed that tissue elastography correctly classifies benign and malignant tissue [6]. The first results for lymph nodes evaluated with EUS elastography and verified with final cytology collected by EUS-FNA showed no false-negatives but five false-positives, resulting in a sensitivity of $100 \%$ and a specificity of $50 \%$ [5].

The authors concluded that the disappointing specificity may improve rapidly with increasing experience and better-defined criteria. A larger study recently showed better diagnostic results with a sensitivity of $100 \%$, a specificity of $83 \%$, a negative predictive value of $100 \%$, and a positive predictive value of $75 \%$ [7].

Whether EUS elastography as virtual biopsy will in some cases replace FNA in the future remains to be established. However, it may function as a guide for selecting the most malignant-appearing lymph node for FNA, consequently reducing the number of false-negative punctures.

Disclosures M. M. C. Hirdes and F. P. Vleggaar have no conflicts of interest or financial ties to disclose.

Open Access This article is distributed under the terms of the Creative Commons Attribution Noncommercial License which 
permits any noncommercial use, distribution, and reproduction in any medium, provided the original author(s) and source are credited.

\section{References}

1. Hirdes MM, Schwartz MP, Tytgat KM, Schlosser NJ, Sie-Go DM, Brink MA, Oldenburg B, Siersema PD, Vleggaar FP (2010) Performance of EUS-FNA for mediastinal lymphadenopathy: impact on patient management and costs in low-volume EUS centers. Surg Endosc 24:2260-2267

2. Catalano MF, Nayar R, Gress F, Scheiman J, Wassef W, Rosenblatt ML, Kochman M (2002) EUS-guided fine-needle aspiration in mediastinal lymphadenopathy of unknown etiology. Gastrointest Endosc 55:863-869

3. Marsman WA, Brink MA, Bergman JJ, Tytgat GN, ten Kate FJ, van Lanschot JJ, Fockens P (2006) Potential impact of EUS-FNA staging of proximal lymph nodes in patients with distal esophageal carcinoma. Endoscopy 38:825-829

4. Larsen SS, Krasnik M, Vilmann P, Jacobsen GK, Pedersen JH, Faurschou P, Folke K (2002) Endoscopic ultrasound-guided biopsy of mediastinal lesions has a major impact on patient management. Thorax 57:98-103

5. Giovannini M, Hookey LC, Bories E, Pesenti C, Monges G, Delpero JR (2006) Endoscopic ultrasound elastography: the first step towards virtual biopsy? Preliminary results in 49 patients. Endoscopy 38:344-348

6. Giovannini M (2009) Contrast-enhanced endoscopic ultrasound and elastosonoendoscopy. Best Pract Res Clin Gastroenterol 23:767-779

7. Giovannini M, Thomas B, Erwan B, Christian P, Fabrice C, Benjamin E, Genevieve M, Paolo A, Pierre D, Robert Y, Walter S, Hanz S, Carl S, Christoph D, Pierre E, Jean-Luc VL, Jacques D, Peter V, Andrian S (2009) Endoscopic ultrasound elastography for evaluation of lymph nodes and pancreatic masses: a multicenter study. World J Gastroenterol 15:1587-1593 